\title{
UTILIZATION OF INTERNET-BASED LEARNING MEDIA IN ENHANCING SCIENCE LITERACY CAPABILITIES OF PGSD STUDENTS
}

\author{
Asep Samsudin ${ }^{1}$, Jajang Bayu Kelana ${ }^{2}$, Agni Muftianti ${ }^{3}$ \\ ${ }^{1}$ Institut Keguruan dan Ilmu Pendidikan Siliwangi \\ ${ }^{2}$ Institut Keguruan dan Ilmu Pendidikan Siliwangi \\ ${ }^{3}$ Institut Keguruan dan Ilmu Pendidikan Siliwangi \\ ${ }^{1}$ asepsamsudin234@gmail.com, ${ }^{2}$ jajang-bayu@ ikipsiliwangi.co.id, ${ }^{3}$ agnimuftianti@ gmail.com
}

\begin{abstract}
This study was to determine the effect of using internet-based learning media in improving the science literacy skills of PGSD students. The method used is a pre-experimental research design with one group pretest-posttest. The population in this study were all PGSD IKIP Siliwangi students in the fourth semester of regular classes and non-regular classes with a total of 300 students with a sample of 38 regular students. The instruments used included tests, validation sheets and observation sheets. The results showed that the value of sig. (2-tailed) $0,000<0.05$, it can be concluded that there are differences in the average ability of scientific literacy between pretest and posttest and it can be concluded that the use of internet-based learning media can improve students' scientific literacy skills. Student observation data shows that learning using internet-based learning media can increase student activity with a percentage of $53.75 \%$ of active students and $46.25 \%$ of students fasive in learning.
\end{abstract}

Keywords: Learning Media, Internet, Science Literacy

\begin{abstract}
Abstrak
Penelitian ini adalah untuk mengetahui pengaruh penggunaan media pembelajaran berbasis internet dalam meningkatkan keterampilan literasi sains siswa PGSD. Metode yang digunakan adalah praeksperimental dengan desain penelitian one group pretest-posttest. Populasi dalam penelitian ini adalah semua siswa PGSD IKIP Siliwangi pada semester empat kelas reguler dan kelas non reguler dengan total 300 siswa dengan sampel kelas reguler sebanyak 38 mahasiswa. Instrumen yang digunakan termasuk tes, lembar validasi dan lembar observasi. Hasil penelitian menunjukkan bahwa nilai sig. (2-tailed) $0,000<0,05$, dapat disimpulkan bahwa ada perbedaan rata-rata kemampuan literasi sains antara pretest dan posttest dan dapat disimpulkan bahwa penggunaan media pembelajaran berbasis internet dapat meningkatkan keterampilan literasi sains siswa. Data pengamatan siswa menunjukkan bahwa pembelajaran menggunakan media pembelajaran berbasis internet dapat meningkatkan aktivitas siswa dengan persentase 53,75\% siswa aktif dan 46,25\% siswa fasive dalam belajar.
\end{abstract}

Kata Kunci: Media Pembelajaran, Internet, Literasi Sains

\section{INTRODUCTION}

Education is something that is not carried out carelessly, but there is a process and purpose. Starting from conscious effort and culminating in the process of forming attitudes, developing the noble intelligence and skills of students according to their needs. At every level of education is no exception for universities (PGSD), students must take a number of specific subjects, including natural sciences (IPA). Literally science comes from the word natural sciences. Natural means natural, while science means science, then Indonesian 
science becomes science. According to Bundu (Kelana, 2018) explains that science is an activity process carried out by scientists in acquiring certain knowledge and attitudes. Whereas Sujana (2013) explains science or science is a study of the universe and the events that occur in it, developed by experts in a scientific process. It can be concluded that science is an activity that examines nature and the processes in it through scientific processes.

Based on data released by TIMSS (trends in international mathematics and science study) Indonesia is in the position of 35 out of 49 participants in science. While the TIMSS data in 2015, Indonesia ranked 46th out of 51 countries. Based on these data, it can be said that the ability of science in Indonesia is still very low. One of the reasons is the still weak culture of science in Indonesia. Mastery of science material is still not able to connect with complex or abstract topics. Reality in the field shows many difficulties when learning science. Science is seen as less interesting and boring learning, as a result the science learning outcomes are quite low. For this reason, a prospective teacher needs to have an understanding of the importance of science or a broader range of scientific literacy.

OECD (2018) define scientific literacy as the capacity to use scientific knowledge, identify questions and draw conclusions based on evidence to help make decisions about the natural world and the changes made to it through human activities. Whereas Kelana (2017) explains that scientific literacy is the ability to use scientific knowledge, identify questions and draw conclusions based on science with the dimensions of the process, content and context of the application of science. It can be concluded that scientific literacy is an ability developed to acquire knowledge related to science.

In order to develop scientific literacy skills, a variety of learning is needed. One of them is the use of learning media. The National Education Association (in Rusman: 2013) defines learning media as a means of communication in the form of channels used to convey messages / information. Whereas according to Uno and Lamatenggo (2011) states that learning media is all forms of communication tools that can be used to convey information from sources to peseta educators. From this opinion it can be concluded that learning media is a means or communication tool used to increase the effectiveness of message/information delivery. In the end students are able to receive all messages / information well and thoroughly.

The research conducted by Gultom (2016) on the effect of using internet-based learning media and learning independence on student learning achievement shows that the internet-based learning media can improve student learning outcomes. Kelana (2018) about 
The Effect of Learning Media and The Ability To Think of Creative Science The Student of Elementary School shows that there is an influence of the use of learning media and creative thinking on scientific literacy skills. From these data, researchers are interested in conducting research with the title of the use of internet-based learning media in enhancing the ability of PGSD student scientific literacy.

\section{METHOD}

The method used in this study is pre-experimental. The research design used was one group pretest-posttest. According to Solomon (Maulana, 2009) the design drawings are as follows.

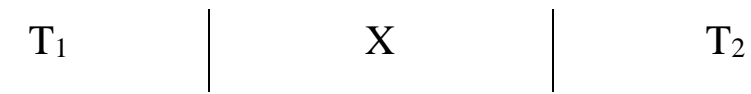

Figure 1. Research Design of one group pretest-posttest

Information:

$\mathrm{T}_{1}=$ Pretest

$\mathrm{T}_{2}=$ Posttest

$\mathrm{X}=$ Treatment

The study was conducted at IKIP Siliwangi Bandung, having its address at JL. Trs Jendral Sudirman-Cimahi. The population in this study were all PGSD students in the fourth semester of regular and non-regular classes with 300 students. The sample in the study was regular class students with 38 students.

The instrument used is an observation instrument that is adapted to indicators of scientific literacy skills. Instruments that have been made are validated to experts and to the field. The instruments used at the pretest and posttest were processed and analyzed using the help of the SPSS 23.0 for Windows application.

\section{RESULTS AND DISCUSSION}

\section{Results}

The results of the study on the use of internet-based learning media in improving scientific literacy skills of the PGSD students showed an increase, this can be seen from the results of data processing and analysis using the help of the SPSS 23.0 for Windows application. 
Table 1. Paired Samples Statistics

\begin{tabular}{lllrrr}
\hline & & & \multicolumn{2}{c}{$\begin{array}{c}\text { Std. } \\
\text { Deviation }\end{array}$} & $\begin{array}{c}\text { Std. Error } \\
\text { Mean }\end{array}$ \\
\hline Pair 1 & Pre test & 34.2105 & 38 & 10.62419 & 1.72347 \\
\cline { 2 - 6 } & Post test & 44.3421 & 38 & 11.80764 & 1.91545 \\
\hline
\end{tabular}

From the data above, the average pretest score is 34.21 while for the posttest average value is 44.34. Std value. The deviation at the pretest was 10.62 and the posttest was 11.80 . Std value. the mean error at pretest was 1.72 and the posttest was 1.91 . If interpreted into a graph are as follows.

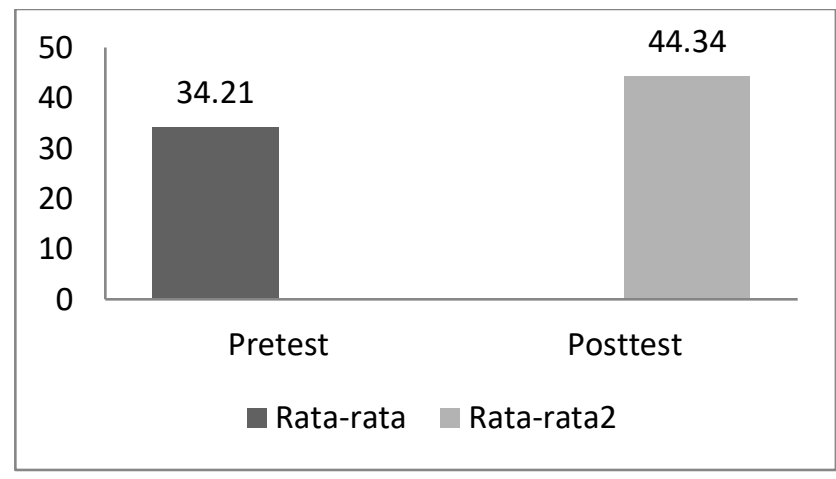

Figure 1. Average value

The results of processing using the $\mathrm{T}$ test show the pretest value of $34.21<$ posttest value 44.34 , descriptively there is a difference in the average science literacy ability. For proof, it is necessary to interpret further.

Table 2. Paired Samples Correlations

\begin{tabular}{llrrr}
\hline & N & Correlation & \multicolumn{1}{c}{ Sig. } \\
\hline Pair 1 & $\begin{array}{l}\text { Pre test \& Post } \\
\text { test }\end{array}$ & 38 & .642 & .000 \\
\hline
\end{tabular}

From the data above, it is known that the correlation coefficient is 0.642 with the sig value. 0,000 . Because the sig value. $0,000<$ probability of 0.05 , it can be concluded that there is a relationship between pretest and posttest data.

Table 3. Paired Samples Test

\begin{tabular}{lll}
$\mathrm{t}$ & $\mathrm{df}$ & Sig. (2-tailed) \\
\hline-6.540 & 37 & .000 \\
\hline
\end{tabular}

The data in table 3 are the most important data from the results of this study, as for the hypothesis what is formulated is: 
$\mathrm{H}_{0}=$ there is no difference in the average scientific literacy ability between pretest and posttest.

$\mathrm{H}_{1}=$ there are differences in the average scientific literacy ability between pretest and posttest.

The hypothesis testing criteria with a significance level $(\alpha=0.05)$ are as follows:

If the value is sig. (2-tailed) $<\alpha$, then $\mathrm{H}_{0}$ is rejected.

If the value is sig. (2-tailed) $>\alpha$, then $\mathrm{H}_{0}$ is accepted.

Based on the data above, the sig value. (2-tailed) $0,000<0,05$, it can be concluded that $\mathrm{H} 0$ is rejected and $\mathrm{H} 1$ is accepted. Thus there is a difference in the average scientific literacy ability between pretest and posttest. Broadly speaking, it can be concluded that the use of internet-based learning media can improve students' scientific literacy skills.

\section{Discussion}

The first meeting begins with a pretest giving to students, the results of data processing show that the pretest results are 34.21. When working on the question, it appears that students have difficulty when answering questions given by the researcher. This happens because students are not familiar with the questions given. At the second meeting, students were divided into several groups and researchers began introducing materials related to scientific literacy. Material deepening related to the topic of discussion can be accessed by students through the internet.

In the learning process there are several obstacles, namely the disconnection of available wifi networks so that the learning process has been disrupted. In addition, the infusion that was used during the execution had died. Constraints that occur in the first learning become material for evaluation in subsequent learning. At the next meeting, the obstacles that occurred at the previous meeting could be overcome and the learning was in accordance with what had been planned.

The observation results also showed students activeness with a percentage of $53.75 \%$. Although not too large, this can prove that learning through the help of internet media can increase student activity. At the last meeting, the researcher conducted a posttest. Posttest data is 44.34. The data is then processed with the help of the SPSS 23.0 for Windows application. The processing results show that the sig value. (2-tailed) $0,000<0,05$, in other words $\mathrm{H}_{0}$ is rejected and $\mathrm{H}_{1}$ is accepted. So it can be concluded that the use of internet-based learning media can improve students' scientific literacy skills. 


\section{CONCLUSION}

Based on the results and findings of the research that has been explained previously the conclusions of this study are 1) learning by utilizing internet-based learning media can improve scientific literacy skills of PGSD students at IKIP Siliwangi; 2) requires sufficient planning to provide meaningful learning when it is later presented in teaching.

\section{ACKNOWLEDGMENTS}

Thank you to IKIP Siliwangi for providing research funding through an internal research program so that this research can be carried out smoothly according to the targets and objectives.

\section{REFERENCES}

Gultom, R. W. (2016). Pengaruh Penggunaan Media Pembelajaran Berbasis Internet dan Kemandirian Belajar Terhadap Prestasi Belajar Siswa Kelas XI IPS SMA Negeri 6 Medan Tahun Pembelajaran 2015/2016. Undergraduate thesis, UNIMED.

Kelana, J. B. (2018), the Effect of the Learning Media and the Ability To Think Creative of To the Ability To Science Literacy Student of Elementary School. PrimaryEdu Journal of Primary Education, 2(2), 79. https://doi.org/10.22460/pej.v2i2.1008

Maulana. (2009). Memahami Hakikat, Variabel, dan Instrumen Penelitian Pendidikan dengan Benar. Bandung: Learn2live „,n Live2Learn.

OECD. "Scientific Literacy Definition," https://stats.oecd.org/glossary/detail.asp?ID=5425 (diakses 2 Juli 2019).

Rusman (2013). Belajar dan Pembelajaran Berbasis Komputer. Alfabeta: Bandung.

Sujana, A. (2013). Pendidikan IPA Teori dan Praktik. Bandung:Rizqi Press.

Uno, B. H dan Lamatenggo, N. (2011). Teknologi Komunikasi dan Informasi Pembelajaran. Jakarta: Bumiaksara.

Undang-Undang Pendidikan No 20 tahun 2003. 